ECONOMICA

Journal of Economic and Economic Education Vol.1 No.1 (32-43)

\title{
ANALISIS PEREKONOMIAN DAERAH DAN PENDAPATAN ASLI DAERAH KABUPATEN/KOTA DI PROVINSI SUMATERA BARAT
}

\author{
Jolianis \\ Dosen Program Studi Pendidikan Ekonomi STKIP- PGRI Sumbar \\ Jl. Gunung Pangilun No.1, Padang Sumatera Barat \\ Email: jolianiskoto@ymail.com \\ Submitted: 2012.09.10 Reviewed: 2012.09.30 Accepted: 2012.10.18 \\ http://dx.doi.org/10.22202/economica.2012.v1.i1.103
}

\begin{abstract}
This study aims to identify and analyze: 1) the effect of household consumption, private investment, and development spending revenue to the regional economy, 2) the effect of private investment, construction spending, employment and regional economy on local income. This study is an exploration studies conducted throughout the Kabupaten/Kota is as much as 19 districts / cities in West Sumatra province. Years of the study period was 2005 to 2009 (5 years). The study found that: 1) household consumption, private investment, and development spending revenue simultaneously or partially significant effect on the regional economy regencies / cities in West Sumatra province. The higher the level of household consumption of a region, the allocation of development spending is high, the amount of private investment that invested in the area and the higher revenues will be able to improve the condition of the local economy. 2) Private investment, construction spending, employment and regional economy simultaneously and partially significant effect on revenue Kabupaten/Kota in West Sumatra province. A growing number of private parties to invest in the area, the size of the allocation of development funds for various public sector facilities, the more labor is absorbed by the sector of the economy will be able to increase local income.
\end{abstract}

\begin{abstract}
Abstrak
Penelitian ini bertujuan untuk mengidentifikasi dan menganalisis: 1) pengaruh konsumsi rumah tangga, investasi swasta, dan pendapatan belanja pembangunan ekonomi regional, 2) pengaruh investasi swasta, belanja konstruksi, pekerjaan dan perekonomian daerah pada pendapatan daerah. Penelitian ini merupakan penelitian eksplorasi yang dilakukan di seluruh Kabupaten / Kota sebanyak 19 kabupaten / kota di provinsi Sumatera Barat. Tahun periode penelitian adalah 2005-2009 (5 tahun). Studi ini menemukan bahwa: 1) konsumsi rumah tangga, investasi swasta, dan pendapatan belanja pembangunan secara simultan maupun parsial berpengaruh signifikan pada daerah kabupaten ekonomi / kota di provinsi Sumatera Barat. Semakin tinggi tingkat konsumsi rumah tangga dari daerah, alokasi belanja pembangunan yang tinggi, jumlah investasi swasta yang berinvestasi di daerah dan pendapatan yang lebih tinggi akan dapat meningkatkan kondisi ekonomi lokal. 2) Investasi swasta, belanja konstruksi, pekerjaan dan perekonomian daerah secara simultan dan secara parsial berpengaruh signifikan pada pendapatan Kabupaten / Kota di Provinsi Sumatera Barat. Semakin banyak pihak swasta untuk berinvestasi di daerah, ukuran alokasi dana pembangunan untuk berbagai fasilitas sektor publik, semakin banyak tenaga kerja yang diserap oleh sektor ekonomi akan dapat meningkatkan pendapatan daerah.
\end{abstract}

Keywords: Household consumption, private investment, development expenditure, local income 


\section{PENDAHULUAN}

Pembangunan perekonomian daerah merupakan suatu proses pemerintah daerah dan masyarakatnya dalam mengelola sumberdaya yang ada untuk merangsang perkembangan kegiatan ekonomi dalam wilayah tersebut. Salah satu indikator penting untuk mengetahui kondisi perekonomian suatu daerah dalam suatu periode tertentu adalah data Produk Domestik Regional Bruto (PDRB) atas dasar harga berlaku. PDRB atas dasar harga berlaku menggambarkan nilai tambah barang dan jasa yang dihasilkan oleh penduduk dan dihitung menggunakan harga yang berlaku. Artinya, PDRB atas dasar harga berlaku merupakan gambaran perekonomian suatu daerah karena semakin tinggi PDRB atas harga berlaku suatu daerah merupakan indikasi semakin baiknya perekonomian daerah yang bersangkutan.

Adapun perkembangan perekonomian provinsi Sumatera Barat yang diukur dari PDRB atas dasar harga berlaku dan pendapatan asli daerah Provinsi Sumatera Barat Periode 2005 - 2009 dapat dilihat pada tabel berikut ini :

Tabel 1. Perkembangan Perekonomian Daerah dan PAD Provinsi Sumatera Barat Periode 2005 - 2009

\begin{tabular}{cccccc}
\hline No & Tahun & $\begin{array}{c}\text { Perekonomian Daerah (Milyar } \\
\text { Rp) }\end{array}$ & $\begin{array}{c}\text { Perubahan } \\
(\boldsymbol{\%})\end{array}$ & $\begin{array}{c}\text { PAD } \\
\text { (Milyar Rp) }\end{array}$ & $\begin{array}{c}\text { Perubahan } \\
(\boldsymbol{\%})\end{array}$ \\
\hline 1 & 2005 & $43.929,05$ & - & 291,73 & - \\
2 & 2006 & $51.385,95$ & 16,97 & 372,15 & 27,57 \\
3 & 2007 & $58.672,90$ & 14,19 & 442,13 & 18,80 \\
4 & 2008 & $68.727,97$ & 17,14 & 529,69 & 19,80 \\
5 & 2009 & $73.824,88$ & 7,42 & 553,75 & 4,54 \\
\hline
\end{tabular}

Sumber: BPS Provinsi Sumatera Barat, 2011

Dari data di atas terlihat bahwa kondisi perekonomian yang diukur berdasarkan PDRB harga berlaku dan pendapatan asli daerah (PAD) provinsi Sumatera Barat secara kuantitas mengalami peningkatan setiap tahunnya namun permasalahannya terlihat bahwa pendapatan asli daerah dan perekonomian daerah persentase peningkatannya mengalami perubahan yang berfluktuasi setiap tahunnya karena idealnya dalam perekonomian diharapkan adanya peningkatan pendapatan asli daerah dan perekonomian daerah secara positif setiap tahunnya, tentunya kejadian ini tidak baik berlangsung lama karena memberikan dampak buruk terhadap pembangunan perekonomian daerah Sumatera Barat dalam mewujudkan kemandirian daerah dalam menjalani otonomi daerah.

Dari data di atas terlihat penulis menduga bahwa ada keterkaitan antara pendapatan asli dengan perekonomian daerah dan sebaliknya, karena apabila terjadi perubahan dari pendapatan asli daerah meyebabkan terjadinya perubahan pada perekonomian daerah dan begitu juga sebaliknya. Dengan demikian penulis menduga bahwa apabila pendapatan asli daerah mengalami peningkatan akan meningkatkan perekonomian daerah, begitu juga sebaliknya bahwa apabila perekonomian daerah mengalami peningkatan tentunya akan dapat meningkatkan pendapatan asli daerah.

Penulis menduga terjadinya perubahan yang berfluktuasi dari perekonomian daerah dan pendapatan asli daerah di provinsi Sumatera Barat tentunya disebabkan oleh banyak hal. Faktor yang berkemungkinan dominan mempengaruhi perekonomian daerah Sumatera Barat adalah konsumsi rumah tangga, investasi swasta, belanja pembangunan, dan pendapatan asli daerah. Selanjutnya penulis menduga bahwa faktor yang berkemungkinan dominan mempengaruhi pendapatan asli daerah Sumatera Barat adalah investasi swasta, belanja pembangunan, tenaga kerja dan perekonomian daerah.

Adapun perkembangan pengeluaran konsumsi rumah tangga, investasi swasta, belanja pembangunan dan tenaga kerja di Sumatera Barat selama 5 tahun terakhir adalah sebagai berikut: 
Tabel 2. Konsumsi Rumah Tangga, Belanja Pembangunan, Investasi Swasta dan Tenaga Kerja di Provinsi Sumatera Barat Periode 2005-2009

\begin{tabular}{|c|c|c|c|c|c|c|c|c|c|}
\hline $\begin{array}{l}\mathbf{N} \\
\mathbf{o}\end{array}$ & Thn & $\begin{array}{l}\text { Konsumsi RT ADHB } \\
\text { (Milyar Rp) }\end{array}$ & $(\%)$ & $\begin{array}{c}\text { Investasi } \\
\text { Swasta (Milyar } \\
\text { Rp) }\end{array}$ & $(\%)$ & $\begin{array}{c}\text { Belanja } \\
\text { Pmbngunn } \\
\text { (Milyar Rp) }\end{array}$ & $(\%)$ & $\begin{array}{l}\text { Tenaga Kerja } \\
\text { (Ribu Orang) }\end{array}$ & $(\%)$ \\
\hline 1 & 2005 & $22.445,99$ & - & $8.213,51$ & - & 612,19 & - & $1.542,79$ & \\
\hline 2 & 2006 & $26.447,60$ & 17,83 & $9.389,75$ & 14,32 & $1.279,25$ & 108,96 & $1.627,64$ & 5,50 \\
\hline 3 & 2007 & $30.019,01$ & 13,50 & $14.671,10$ & 56,24 & $2.028,25$ & 58,54 & $1.808,91$ & 11,14 \\
\hline 4 & 2008 & $35.545,80$ & 18,41 & $16.674,63$ & 13,66 & $2.281,22$ & 12,47 & $2.004,67$ & 10,82 \\
\hline 5 & 2009 & $40.037,77$ & 12,64 & $14.550,66$ & 12,73 & $2.369,54$ & 3,87 & $2.039,63$ & 1,74 \\
\hline
\end{tabular}

Sumber : BPS Provinsi Sumatera Barat, 2011

Dari data di atas dapat dilihat bahwa konsumsi rumah tangga secara kuantitas mengalami peningkatan setiap tahunnya namun persentase peningkatannya berfluktuasi setiap tahun. Hal ini mengindikasikan bahwa relatif kurang stabilnya tingkat pendapatan rumah tangga sehingga menyebabkan terjadinya perubahan terhadap total konsumsi rumah tangga. Selanjutnya jika dikaitkan antara konsumsi rumah tangga dengan perekonomian daerah terlihat bahwa perubahan pada tingkat konsumsi rumah tangga hampir sebanding dengan perubahan perekonomian daerah. Sebagai bukti bahwa pada tahun 2007 dan tahun 2009 terlihat bahwa persentase peningkatan dari konsumsi rumah tangga seiring dengan persentase peningkatan dari perekonomian daerah lebih kecil dari tahun sebelumnya.

Investasi swasta secara kuantitas mengalami peningkatan dari tahun 20062008 tetapi persentase perubahannya mengalami perubahan yang berfluktuasi. Namun pada tahun 2009 terjadi penurunan dari jumlah investasi swasta sebesar $12,73 \%$. Terjadinya penurunan investasi swasta ini tentunya sangat tidak diharapkan karena idealnya investasi swasta tersebut harus mengalami peningkatan setiap tahun agar dapat memberikan kontribusi terhadap pendapatan asli daerah dan perekonomian daerah. Jika dilihat hubungan investasi swasta dengan pendapatan asli daerah dan perekonomian daerah, terlihat bahwa penurunan yang terjadi pada tahun 2009 juga menyebabkan terjadi penurunan persentase pertumbuhan pendapatan asli daerah dan perekonomian daerah.

Belanja pembangunan yang dialokasikan oleh pemerintah provinsi Sumatera Barat pada tahun 2005 - 2009 secara kuantitas mengalami peningkatan namun persentase peningkatannya mengalami penurunan setiap tahunnya. Jika belanja pembangunan dikaitkan dengan perekonomian daerah dan pendapatan asli daerah maka masalah yang terlihat yaitu pada tahun 2009 terjadi penurunan yang cukup tajam dari belanja pembangunan dan begitu juga dengan pendapatan asli daerah dan perekonomian daerah provinsi Sumatera Barat.

Jumlah tenaga kerja yang diserap oleh sektor perekonomian di Sumatera Barat secara kuantitas mengalami peningkatan setiap tahun tetapi persentase pertumbuhannya mengalami perubahan yang berfluktuasi. Selanjutnya jika dikaitkan jumlah tenaga kerja dengan pendapatan asli daerah terlihat bahwa perubahan jumlah tenaga kerja berdampak terhadap pendapatan asli daerah yang dibuktikan bahwa pada tahun 2009 persentase pertumbuhan jumlah tenaga kerja dan pendapatan asli daerah sama-sama menurun dari tahun sebelumnya. Dengan demikian dapat diasumsikan bahwa terjadinya peningkatan atau penurunan dari jumlah tenaga kerja yang diserap oleh sektor perekonomian akan mempengaruhi pendapatan asli daerah provinsi Sumatera Barat karena tenaga kerja merupakan sumber daya potensial sebagai penggerak, penggagas dan pelaksana dari pada pembangunan di daerah tersebut, sehingga dapat memajukan daerah.

Dari latar belakang masalah yang telah diuraikan di atas maka pokok masalah yang akan dikaji dalam penelitian ini dapat dirumuskan sebagai berikut:

1. Seberapa besar pengaruh konsumsi rumah tangga, belanja pembangunan dan investasi swasta dan pendapatan asli daerah terhadap 
perekonomian daerah Kabupaten/Kota di Provinsi Sumatera Barat?

2. Seberapa besar pengaruh investasi swasta, belanja pembangunan, tenaga kerja dan perekonomian daerah terhadap pendapatan asli daerah Kabupaten/Kota di Provinsi Sumatera Barat?

\section{METODE PENELITIAN}

Penelitian ini merupakan studi ekplorasi yang dilakukan pada seluruh pemerintahan Kabupaten / Kota yaitu sebanyak 19 Kabupaten/Kota di Provinsi Sumatera Barat. Penelitian ini akan melakukan analisis potensi dan perekonomian daerah Kabupaten/Kota di Provinsi Sumatera Barat.

\section{A. Variabel Penelitian}

\section{Perekonomian Daerah $\left(\mathbf{Y}_{1}\right)$}

Perekonomian daerah yang dimaksud pada penelitian ini keadaan perekonomian Kabupaten/Kota di Provinsi Sumatera Barat selama 5 tahun terakhir yang di ukur berdasarkan PDRB atas dasar harga berlaku yang menggambarkan nilai tambah barang dan jasa. Variabel perekonomian daerah diukur dalam satuan rupiah (Milyar Rupiah).

\section{Pendapatan Asli Daerah $\left(\mathbf{Y}_{2}\right)$}

Pendapatan asli daerah yang dimaksud pada penelitian ini total pendapatan asli daerah (PAD) Kabupaten/Kota di Provinsi Sumatera Barat selama $\mathrm{t}$ tahun terakhir. Variabel potensi daerah ini diukur dalam satuan rupiah (Milyar Rupiah).

\section{Konsumsi Rumah Tangga $\left(\mathrm{X}_{1}\right)$}

Konsumsi rumah tangga yang dimaksud pada penelitian ini adalah besarnya tingkat konsumsi rumah tangga setiap tahun pada masing-masing Kabupaten/Kota di Provinsi Sumatera Barat. Variabel konsumsi rumah tangga pada penelitian ini diukur dalam satuan rupiah (Milyar Rupiah)

\section{Investasi Swasta $\left(\mathbf{X}_{2}\right)$}

Investasi swasta yang dimaksud pada penelitian ini adalah total investasi swasta yang ditanamkan pada masing-masing daerah Kabupaten/Kota di Sumatera Barat yang dinyatakan dalam rupiah. Variabel investasi pada penelitian ini diukur dalam satuan rupiah (Milyar Rupiah)

\section{Belanja Pembangunan $\left(\mathbf{X}_{3}\right)$}

Belanja pembangunan yang dimaksud pada penelitian ini adalah total belanja pembangunan yang dikeluarkan oleh masingmasing pemerintah Kabupaten/Kota di Provinsi Sumatera Barat Besarnya dana belanja pembangunan ini dapat dilihat dari realisasi belanja modal pada Kabupaten/kota Provinsi Sumatera Barat. Variabel Belanja pembangunan pada penelitian ini diukur dalam satuan rupiah (Milyar Rupiah)

\section{Tenaga Kerja $\left(\mathbf{X}_{4}\right)$}

Tenaga kerja yang dimaksud dalam penelitian ini adalah jumlah angkatan kerja yang bekerja pada sektor perekonomian pada masing-masing daerah Kabupaten/Kota di Sumatera Barat. Variabel tenaga kerja pada penelitian ini diukur dalam satuan ribu orang.

\section{B. Model Analisis}

Model analisis yang digunakan untuk melihat pengaruh dari variabel eksogen terhadap variabel endogen digunakan analisis simultan. Analisis simultan pada penelitian ini digunakan untuk melihat hubungan antara perekonomian daerah dengan pendapatan asli daerah dengan variabel-variabel yang mempengaruhinya. Persamaan yang digunakan adalah sebagai berikut :

$\mathrm{Y}_{1}=\alpha_{0}+\alpha_{1} \mathrm{X}_{1}+\alpha_{2} \mathrm{X}_{2}+\alpha_{3} \mathrm{X}_{3}+\alpha_{5} \mathrm{Y}_{2}+\mathrm{Ut} \alpha_{0}$

$Y_{2}=\beta_{0}+\beta_{2} X_{2}+\beta_{3} X_{3}+\beta_{4} X_{4}+\beta 6 Y_{1}+U_{10}$

Dimana :

$\mathrm{Y}_{1} \quad=$ Perekonomian daerah

Y2 = Pendapatan asli daerah

$\mathrm{X}_{1} \quad=$ Konsumsi Rumah Tangga

$\mathrm{X}_{2}=$ Investasi Swasta

$\mathrm{X}_{2} \quad=$ Belanja pembangunan

$\mathrm{X}_{4}=$ Tenaga kerja

Dalam persamaan simultan untuk mengetahui apakah estimasi parameter dapat dilakukan melalui persamaan reduced form dari sistem persamaan simultan atau tidak, maka perlu adanya identifikasi. Masalah identifikasi menurut Sumodiningrat (2007:274) dapat dilakukan melalui order condition dan rank condition. Jadi metode simultan yang dapat digunakan pada penelitian ini adalah Ordinary Least Squared (OLS) atau disingkat karena persamaan simultan tersebut bersifat exactly identified. 


\section{PEMBAHASAN}

\section{Deskriptif Variabel Penelitian}

Pada sub bab ini peneliti akan menjelaskan mendiskripsikan variabel penelitian. Masing-masing variabel penelitian akan dideskripsikan dengan menerangkan nilai rata-rata, nilai terendah dan tertinggi agar dapat memberikan kesimpulan tentang perkembangan konsumsi rumah tangga, investasi swasta, belanja pembangunan, tenaga kerja, pendapatan asli daerah dan perekonomian daerah Kabupaten/Kota di Provinsi Sumatera Barat periode 2005 - 2009.

1. Rata-rata perekonomian daerah Kabupaten/Kota di Provinsi Sumatera Barat adalah sebesar 3.146,35 milyar dengan nilai tertinggi adalah 21.896,37 milyar dan nilai terendah sebesar 468,22 milyar. Hal ini mengindikasikan bahwa adanya perbedaan kondisi perekonomian daerah antara Kabupaten/Kota di Provinsi Sumatera Barat yang dibuktikan oleh besarnya jarak antara nilai tertinggi dengan nilai terendah dari perekonomian daerah. Selanjutnya jika diperhatikan kondisi perekonomian daerah yang memiliki PDRB tertinggi adalah Kota Padang dengan nilai rata-rata yaitu sebesar 17.654,53 milyar pertahun dan daerah yang memiliki PDRB terendah adalah Kota Padang Panjang dengan nilai rata-rata yaitu sebesar 643.64 milyar pertahun.

2. Rata-rata pendapatan asli daerah Kabupaten/Kota di Provinsi Sumatera Barat adalah 23,19 milyar pertahun dan pendapatan asli daerah tertinggi adalah 136,22 milyar dan pendapatan asli daerah terendah sebesar 5,16 milyar. Hal ini mengindikasikan bahwa Kabupaten/Kota di Provinsi Sumatera Barat memiliki kemampuan yang berbeda satu sama lainnya dalam menghimpun pendapatan asli daerahnya. Selanjutnya jika diperhatikan besarnya pendapatan asli daerah masing-masing Kabupaten/Kota di Provinsi Sumatera Barat terlihat bahwa daerah yang memiliki pendapatan asli daerah tertinggi adalah Kota Padang dengan nilai rata-rata yaitu sebesar 112.63 milyar pertahun dan daerah yang memiliki pendapatan asli daerah terendah adalah Kota Pariaman dengan nilai ratarata yaitu sebesar 9,45 milyar pertahun. Hal ini mengindikasikan bahwa Kota Padang memiliki kemampuan dan potensi yang tinggi dalam meningkatkan pendapatan asli daerah selama periode 2005 - 2009.

3. Rata-rata konsumsi rumah tangga Kabupaten/Kota di Provinsi Sumatera Barat adalah 1,629,27 milyar pertahun dan konsumsi rumah tangga tertinggi adalah 13.725, 55 milyar dan konsumsi rumah tangga terendah sebesar 247,30 milyar. Hal ini mengindikasikan bahwa penduduk pada Kabupaten/Kota di Provinsi Sumatera Barat memiliki tingkat konsumsi rumah tangga yang tinggi setiap tahunnya. Selanjutnya jika diperhatikan besarnya konsumsi rumah tangga masing-masing Kabupaten/Kota di Provinsi Sumatera Barat terlihat bahwa daerah yang memiliki konsumsi rumah tangga tertinggi adalah Kota Padang dengan nilai rata-rata yaitu sebesar 9.932,31 milyar pertahun dan daerah yang memiliki konsumsi rumah tangga terendah adalah Kota Padang Panjang dengan nilai rata-rata yaitu sebesar 379,90 milyar pertahun.

4. Rata-rata investasi swasta pada Kabupaten/Kota di Provinsi Sumatera Barat adalah 674,04 milyar dan nilai tertinggi dari investasi swasta adalah 7.271,70 milyar dan nilai investasi swasta terendah adalah sebesar 121,53 milyar. Hal ini mengindikasikan bahwa Kabupaten/Kota di Provinsi Sumatera Barat memiliki total investasi swasta yang berbeda satu sama lainnya. Selanjutnya jika diperhatikan besarnya investasi swasta pada masing-masing Kabupaten/Kota di Provinsi Sumatera Barat terlihat bahwa daerah yang memiliki total investasi swasta tertinggi adalah Kota Padang dengan nilai rata-rata investasi swasta adalah yaitu sebesar 5.064,31 milyar dan daerah yang memiliki investasi swasta terendah adalah Kota Payakumbuh dengan nilai rata-rata investasi swasta sebesar 154,16 milyar. 
5. Rata-rata belanja pembangunan Kabupaten/Kota di Provinsi Sumatera Barat adalah 90,21 milyar pertahun dan belanja pembangunan tertinggi adalah 205,87 milyar dan belanja pembangunan terendah sebesar 14,72 milyar. Hal ini mengindikasikan bahwa Kabupaten/Kota di Provinsi Sumatera Barat sudah mengalokasikan dana yang cukup besar untuk keperluan belanja pembangunan berupa belanja tanah, peralatan dan mesin, gedung dan bangunan, jalan, irigasi, dan jaringan, aset tetap dan belanja asset lainnya. Selanjutnya jika diperhatikan besarnya belanja pembangunan masing-masing Kabupaten/Kota di Provinsi Sumatera Barat terlihat bahwa daerah yang memiliki alokasi belanja pembangunan tertinggi adalah Kabupaten Lima Puluh Kota dengan nilai rata-rata alokasi belanja pembangunan sebesar 127.49 milyar pertahun dan daerah yang memiliki belanja pembangunan terendah adalah Kota Sawahlunto dengan nilai rata-rata yaitu sebesar 55.92 milyar pertahun.

6. Rata-rata tenaga kerja yang diserap oleh sektor perekonomian Kabupaten/Kota di Provinsi Sumatera Barat adalah 94,95 ribu orang pertahun dan jumlah tenaga kerja tertinggi yang dapat diserap adalah sebanyak 324,15 ribu orang dan jumlah tenaga kerja terendah yang paling sedikit dapat diserap oleh sektor dalam perekonomian daerah adalah sebesar 14,82 ribu orang pertahun. Selanjutnya jika diperhatikan besarnya tenaga kerja masing-masing Kabupaten/Kota di Provinsi Sumatera Barat terlihat bahwa daerah yang mempunyai kemampuan yang tinggi dan mempunyai kemampuan yang tinggi dalam menyerap tenaga kerja adalah Kota Padang dengan nilai rata-rata yaitu sebesar 294.93 ribu orang pertahun dan daerah yang mampu menyerap tenaga kerja paling terendah selama lima tahun terakhir adalah Kabupaten Kepulauan Mentawai dengan nilai ratarata pertahun yaitu sebesar 19.46 ribu orang pertahun.

Uji Persyaratan Analisis

\section{Uji Heteroskedastisitas}

Berdasarkan hasil analisis data untuk uji heteroskedastisitas diperoleh bahwa nilai probability untuk semua variabel nilainya lebih besar dari tingkat signifikan yang digunakan $(\alpha=0,05)$. Jadi dapat dikatakan bahwa data hasil penelitian tidak mengalami kasus heteroskedastsitas.

\section{Uji Autokorelasi}

Berdasarkan hasil analisis data untuk uji autokorelasi persamaan 1 diperoleh nilai Durbin Watson (DW) sebesar 2,23 dan untuk persamaan 2 diperoleh nilai Durbin Watson (DW) sebesar 2,01. Dengan demikian dapat diaktakan bahwa bahwa tidak ada korelasi antara kesalahan pengganggu pada periode $\mathrm{t}$ dengan kesalahan pada periode $\mathrm{t}-1$ (sebelumnya) sehingga data hasil penelitian dapat dianalisis dengan analisis lebih lanjut untuk keperluan penelitian.

\section{Uji Kausalitas Granger}

Pada penelitian ini penulis akan melakukan uji kausalitas dari perekonomian daerah $\left(\mathrm{Y}_{1}\right)$ dengan pendapatan asli daerah $\left(\mathrm{Y}_{2}\right)$. Dari hasil uji Kausalitas Granger didapatkan nilai probability dari variabel pendapatan asli daerah $\left(\mathrm{Y}_{2}\right)$ terhadap perekonomian daerah ( $\left.\mathrm{Y}_{1}\right)$ adalah 0,002 yakni lebih kecil dari $\alpha=$ $0,05(0,002<0,05)$. Nilai probability dari variabel perekonomian daerah $\left(\mathrm{Y}_{1}\right)$ terhadap pendapatan asli daerah $\left(\mathrm{Y}_{2}\right)$ adalah 0,01 yakni kecil dari $\alpha=0,004 \quad(0,004<0,05)$. Berdasarkan hasil uji kausalitas ini maka dapat dkatakan bahwa variabel perekonomian daerah dan pendapatan asli daerah mempunyai hubungan dua arah atau saling mempengaruhi satu sama lainnya. Dengan demikian dapat dikatakan bahwa sesama variabel endogen mempunyai mempunyai hubungan dua arah atau saling mempengaruhi satu sama lainnya sehingga data hasil penelitian dapat dilanjutkan dengan menggunaakan persamaan simultan.

\section{B. Uji Hipotesis}

\section{Hasil Uji Hipotesis Pertama}

Dari hasil estimasi pada persamaan perekonomian daerah diperoleh nilai $F_{\text {hitung }}$ sebesar 197.143,2 dengan nilai probability 0,00 . Jika nilai $F_{h i t u n g}$ dibandingkan dengan 
nilai $F_{\text {tabel }}$ maka terbukti bahwa nilai $F_{\text {hitung }}$ lebih besar dari nilai $F_{\text {tabel }}(197.143,2>2,70)$ dan nilai probability lebih kecil dari alpha $(0,00<0,05)$. Dengan demikian dapat dikatakan bahwa konsumsi rumah tangga, investasi swasta, belanja pembangunan, dan pendapatan asli daerah secara bersama-sama berpengaruh signifikan terhadap perekonomian daerah Kabupaten/Kota di Provinsi Sumatera Barat. Berarti hipotesis pertama yang diajukan pada penelitian ini dapat diterima pada tingkat kepercayaan $95 \%$.

Pengujian hipotesis secara parsial diketahui nilai $t_{\text {hitung }}$ dari variabel konsumsi rumah tangga $\left(\mathrm{X}_{1}\right)$ sebesar 226,98, variabel investasi swasta $\left(\mathrm{X}_{2}\right)$ sebesar 7,31, variabel belanja pembangunan $\left(\mathrm{X}_{3}\right)$ sebesar 41,57 dan variabel pendapatan asli daerah $\left(\mathrm{Y}_{2}\right)$ sebesar 0,068 . Jika nilai $t_{\text {hitung }}$ dibandingkan dengan nilai $t_{\text {tabel }}$ maka terbukti bahwa nilai $t_{\text {hitung }}$ untuk variabel konsumsi rumah tangga, investasi swasta, belanja pembangunan $\left(X_{1}\right.$, $\mathrm{X}_{2}$, dan $\left.\mathrm{X}_{3}\right)$ lebih besar dari nilai $\mathrm{t}_{\text {tabel }}(1,98)$ sedangkan nilai $t_{\text {hitung }}$ untuk variabel pendapatan asli daerah lebih kecil dari nilai $t_{\text {tabel }}(0,068<1,98)$. Dengan demikian dapat dikatakan bahwa secara parsial konsumsi rumah tangga, investasi swasta dan belanja pembangunan berpengaruh signifikan terhadap perekonomian daerah Kabupaten/Kota di Provinsi Barat sedangkan pendapatan asli daerah secara parsial tidak berpengaruh signifikan terhadap perekonomian daerah Kabupaten/Kota di Provinsi Sumatera Barat.

\section{Hasil Uji Hipotesis Kedua}

Dari hasil estimasi pada pendapatan asli daerah diperoleh nilai $F_{\text {hitung }}$ sebesar $1.268,17$ dengan nilai probability 0,00 . Jika nilai $F_{\text {hitung }}$ dibandingkan dengan nilai $F_{\text {tabel }}$ maka terbukti bahwa nilai $F_{\text {hitung }}$ lebih besar dari nilai $\mathrm{F}_{\text {tabel }}(1.268,17>2,70)$ dan nilai probability lebih kecil dari alpha $(0,00<$ 0,05). Dengan demikian dapat dikatakan bahwa investasi swasta, belanja pembangunan, tenaga kerja dan perekonomian daerah secara bersama-sama berpengaruh signifikan terhadap pendapatan asli daerah Kabupaten/Kota di Provinsi Sumatera Barat. Berarti hipotesis kedua yang diajukan pada penelitian ini dapat diterima pada tingkat kepercayaan $95 \%$.
Pengujian hipotesis secara parsial diketahui nilai $t_{\text {hitung }}$ dari variabel investasi swasta $\left(\mathrm{X}_{2}\right)$ sebesar 12,52, variabel belanja pembangunan $\left(\mathrm{X}_{3}\right)$ sebesar 4,36, variabel tenaga kerja $\left(\mathrm{X}_{4}\right)$ sebesar 10,52 dan variabel perekonomian daerah $\left(\mathrm{Y}_{1}\right)$ sebesar 26,87. Jika nilai $t_{\text {hitung }}$ dibandingkan dengan nilai $t_{\text {tabel }}$ maka terbukti bahwa nilai $t_{\text {hitung }}$ untuk semua variabel dalam persamaan $2\left(\mathrm{X}_{2}, \mathrm{X}_{3}, \mathrm{X}_{4}\right.$, dan $\mathrm{Y}_{1}$ ) lebih besar dari nilai $\mathrm{t}_{\text {tabel }}(1,98)$. Dengan demikian dapat dikatakan bahwa secara parsial investasi swasta, belanja pembangunan, tenaga kerja dan perekonomian daerah berpengaruh signifikan terhadap pendapatan asli daerah Kabupaten/Kota di Provinsi Sumatera Barat.

\section{Pengaruh Konsumsi Rumah Tangga, Investasi Swasta, Belanja Pembangunan dan Pendapatan Asli Daerah Terhadap Perekonomian Daerah Kabupaten/Kota di Provinsi Sumatera Barat}

Berdasarkan hasil pengujian hipotesis pertama diketahui bahwa konsumsi rumah tangga, investasi swasta, belanja pembangunan dan pendapatan asli daerah secara bersama-sama berpengaruh signifikan terhadap perekonomian daerah Kabupaten/Kota di Provinsi Sumatera Barat. Apabila secara bersamaan tingkat konsumsi rumah tangga, investasi swasta, belanja pembangunan dan pendapatan asli daerah mengalami peningkatan tentunya akan dapat meningkatkan perekonomian daerah Kabupaten/Kota di Provinsi Sumatera Barat.

Selanjutnya penelitian ini menemukan bahwa secara parsial konsumsi rumah tangga mempengaruhi perekonomian daerah secara positif. Artinya semakin tinggi tingkat konsumsi rumah tangga akan meningkatkan perekonomian daerah Kabupaten/Kota di Provinsi Sumatera Barat. Artinya meningkatnya konsumsi rumah disebabkan oleh meningkatnya pendapatan masyarakat sehingga masyarakat mempunyai kemampuan yang tinggi untuk menambah jumlah konsumsinya sehingga barang yang jasa yang dihasilkan dalam perekonomian akan dikonsumsi oleh rumah tangga, yang pada gilirannya akan dapat meningkatkan perekonomian daerah Kabupaten/Kota di Provinsi Sumatera Barat. 
Temuan penelitian ini konsisten dengan teori Keynes dalam Dornbusch (2008:190) yang menyoroti hubungan antara konsumsi dan pendapatan rumah tangga, bila pendapatan masyarakat meningkat maka konsumsi juga meningkat. Hal ini menunjukkan kepada kita bahwa bilamana kecenderungan marginal mengkonsumsi tinggi maka permintaan konsumsi, output dan pekerjaan juga meningkat. Dengan demikian temuan penelitian ini membuktikan bahwa peningkatan dari konsumsi rumah tangga pada Kabupaten/Kota di Provinsi Sumatera Barat memberikan pengaruh positif dapat meningkatkan perekonomian daerah. Kabupaten/Kota di Provinsi.

Temuan penelitian ini juga membuktikan bahwa secara parsial investasi swasta berpengaruh signifikan dan positif terhadap perekonomian. Apabila investasi swasta pada masing-masing Kabupaten/Kota di Provinsi Sumatera Barat mengalami peningkatan secara positif setiap tahunnya maka perekonomian daerah Kabupaten/Kota di Provinsi Sumatera Barat juga akan mengalami peningkatan.

Temuan penelitian ini relevan dengan pendapat Jhingan (1999:291) yang memberikan peranan kunci kepada investasi terhadap peranannya dalam kegiatan perekonomian suatu daerah khususnya mengenai peran ganda yang dimiliki investasi. Pertama, investasi memiliki peran ganda dimana dapat menciptakan pendapatan dan kedua investasi memperbesar kapasitas produksi perekonomian dengan cara meningkatkan stok modal sehingga akan memperbaiki kondisi perekonomian. Dengan demikian dapat diketahui bahwa temuan penelitian ini membuktikan bahwa apabila pemerintah daerah Kabupaten/Kota di Provinsi Sumatera dapat meningkatkan total investasi swasta setiap tahunnya tentu akan dapat memberikan pengaruh positif terhadap perekonomian daerah Kabupaten/Kota di Provinsi Sumatera Barat.

Temuan penelitian ini juga membuktikan bahwa secara parsial belanja pembangunan mempengaruhi perekonomian daerah secara signifikan dan positif. Semakin besarnya alokasi belanja pembangunan pada masing-masing Kabupaten/Kota di Provinsi
Sumatera Barat akan dapat memperbaiki infrastruktur yang ada sehingga mendukung terhadap aktivitas perekonomian yang pada gilirannya akan memberikan kontribusi positif terhadap perbaikan kondisi perekonomian daerah.

Hasil penelitian ini relevan dengan pendapat Saragih (2003:115) yang menyatakan bahwa jika pemerintah daerah menetapkan anggaran belanja pembangunan lebih besar dari pengeluaran rutin, maka kebijakan ekspansi anggaran daerah ini akan mendongkrak perekonomian daerah menjadi lebih baik. Dengan demikian dapat diketahui apabila pemerintah daerah Kabupaten/Kota di Provinsi Sumatera dapat meningkatkan alokasi belanja pembangunan setiap tahunnya tentu akan dapat memberikan pengaruh positif terhadap perbaikan kondisi perekonomian daerah Kabupaten/Kota di Provinsi Sumatera Barat.

Temuan penelitian ini juga menemukan bahwa pendapatan asli daerah secara parsial tidak berpengaruh signifikan terhadap perekonomian daerah. Apabila terjadi peningkatan dari pendapatan asli daerah Kabupaten/Kota di Provinsi Sumatera Barat tidak dapat meningkatkan perekonomian daerah. Hal ini disebabkan karena pendapatan asli darah yang diterima oleh Kabupaten/Kota di Provinsi Sumatera Barat habis dipergunakan untuk menutupi biaya-biaya rutin untuk menyelenggarakan pemerintahan daerah sehingga menyebabkan pendapatan asli daerah tersebut belum memberikan pengaruh yang berarti terhadap kondisi perekonomian daerah.

Temuan penelitian tidak konsisten dengan pendapat Kuncoro (2004:64) yang menyatakan bahwa peningkatan pendapatan daerah akan memperbaiki kondisi perekonomian yang diukur dari PDRB atas dasar harga berlaku, sehingga peningkatan realisasi pendapatan asli daerah (PAD) akan memberikan kontribusi positif terhadap pembanguan perekonomian. Dengan deimikian dapat dikatakan bahwa kondisi perekonomian akan dipengaruhi oleh pendapatan asli daerah. Penelitian ini juga tidak konsisten dengan pendapat Tambunan (2006:67) yang menyatakan jika pendapatan asli daerah meningkat maka dana yang 
dimiliki oleh pemerintah daerah akan lebih banyak dan tingkat kemandirian daerah akan meningkat pula, sehingga pemerintah daerah akan memiliki kesempatan yang tinggi untuk membangun perekonomiannya.

Pengaruh Investasi Swasta, Belanja Pembangunan, Tenaga Kerja dan Perekonomian Daerah Terhadap Pendapatan Asli Daerah Kabupaten/Kota di Provinsi Sumatera Barat

Berdasarkan hasil pengujian hipotesis pertama diketahui bahwa investasi swasta, belanja pembangunan, tenaga kerja dan perekonomian daerah secara bersama-sama berpengaruh signifikan terhadap pendapatan asli daerah Kabupaten/Kota di Provinsi Sumatera Barat. Apabila ada peningkatan dari investasi swasta, belanja pembangunan, jumlah tenaga kerja yang diserap dan terjadinya perbaikan dari kondisi perekonomian daerah secara bersamaan tentunya akan dapat meningkatkan pendapatan asli daerah Kabupaten/Kota di Provinsi Sumatera Barat.

Temuan penelitian ini juga menemukan bahwa secara parsial investasi swasta berpengaruh signifikan terhadap pendapatan asli daerah. Apabila jumlah investasi swasta pada daerah mengalami peningkatan setiap tahunnya maka pendapatan asli daerah Kabupaten/Kota di Provinsi Sumatera Barat juga mengalami peningkatan.

Temuan penelitian didukung oleh pendapat Mubyarto (2003:166) yang menyebutkan bahwa pendapatan nasional dalam skala regional kita sebut dengan pendapatan daerah akan mengalami peningkatan ketika terjadi rangsangan investasi. Selanjutnya Kuncoro (2004:98) menyatakan bahwa semakin banyak pihak swasta yang menginvestasikan modalnya pada suatu daerah tentunya akan dapat meningkatkan pendapatan asli daerah.. Dengan demikian maka diketahui bahwa dalam konteks pembangunan regional, investasi memegang peran penting untuk mendorong pendapatan asli daerah.

Temuan penelitian ini membuktikan bahwa secara parsial belanja pembangunan berpengaruh signifikan positif terhadap pendapatan asli daerah. Artinya apabila alokasi belanja pembangunan mengalami peningkatan tentunya akan meningkatkan pendapatan asli daerah Kabupaten/Kota di Provinsi Sumatera Barat.

Temuan penelitian ini didukung oleh pendapat Halim (2001:99) yang menyatakan bahwa dalam penciptaan kemandirian daerah, maka pemerintah daerah juga dituntut untuk mengoptimalkan potensi pendapatan yang dimiliki dan salah satunya memberikan proporsi belanja pembangunan yang lebih besar untuk pembangunan pada sektor-sektor yang produktif di daerah agar pada gilirannya dapat meningkatkan pendapatan asli daerah. Hasil penelitian ini juga didukung oleh pendapat Abimanyu (2005:40) yang menyatakan bahwa pembangunan infrastruktur dan sarana prasarana yang ada di daerah akan berdampak pada peningkatan pendapatan asli daerah. Jika sarana dan prasarana yang dimiliki daerah memadai maka masyarakat dapat melakukan aktivitas sehari-harinya secara aman dan nyaman yang akan berpengaruh pada tingkat produktivitasnya yang semakin meningkat, dan dengan adanya infrastruktur yang memadai akan menarik investor untuk membuka usaha di daerah tersebut. Dengan bertambahnya belanja pembangunan maka akan berdampak pada periode yang akan datang yaitu produktivitas masyarakat meningkat dan bertambahnya investor akan meningkatkan pendapatan asli daerah.

Selanjutnya ditemukan bahwa secara parsial tenaga kerja berpengaruh signifikan terhadap pendapatan asli daerah dan tetapi arah pengaruh tenaga kerja terhadap pendapatan asli daerah adalah negatif. Artinya apabila tenaga kerja meningkat maka pendapatan asli daerah akan mengalami penurunan. Hal ini disebabkan karena masih banyaknya tenaga kerja pada masing-masing Kabupaten/Kota di Provinsi Sumatera Barat yang bekerja pada sektor informal sehingga peningkatan tenaga kerja belum memberikan pengaruh terhadap pendapatan asli daerah.

Temuan penelitian ini tidak konsisten dengan pendapat Mardiasmo (2002:84) yang menyatakan tenaga kerja yang diserap oleh sektor perekonomian pada suatu daerah akan memberikan kontribusi terhadap peningkatan pendapatan asli derah. Apabila sektor 
perekonomian yang ada pada daerah mampu menyerapkan tenaga kerja yang tersedia tentunya akan meningkatkan pendapatan asli daerah tersebut. Juga temuan penelitian ini tidak relevan dengan pendapat Halim (2001:98) menyatakan bahwa pajak penghasilan yang diperoleh dari tenaga kerja merupakan sumber penerimaan daerah yang dapat meningkatkan pendapatan asli daerah

Penelitian ini juga menemukan bahwa secara parsial perekonomian daerah berpengaruh signifikan positif terhadap pendapatan asli daerah. Artinya semakin baik kondisi perekonomian daerah Kabupaten/Kota di Provinsi Sumatera Barat tentunya akan dapat meningkatkan pendapatan asli daerah Kabupaten/Kota di Provinsi Sumatera Barat.

Temuan penelitian ini konsisten dengan pendapat Saragih (2003:67) yang menyatakan bahwa setiap terjadi perubahan kondisi perekonomian akan memberikan dampak berarti terhadap perubahan pendapatan asli daerah (PAD). Daerah yang memiliki perekonomian yang baik akan memiliki pendapatan asli daerah yang tinggi.

\section{PENUTUP}

\section{Kesimpulan}

Berdasarkan hasil penelitian dan pembahasan, maka penelitian ini dapat disimpulkan sebagai berikut :

1. Konsumsi rumah tangga, investasi swasta, belanja pembangunan dan pendapatan asli daerah secara simultan berpengaruh signifikan terhadap perekonomian daerah Kabupaten/Kota di Provinsi Sumatera Barat. Semakin tinggi tingkat konsumsi masyarakat suatu daerah, adanya alokasi belanja pembangunan yang tinggi pada masingmasing daerah, semakin banyaknya investasi swasta yang ditanamkan pada daerah dan semakin tinggi pendapatan asli daerah tentunya akan dapat memperbaiki kondisi perekonomian Kabupaten/Kota di Provinsi Sumatera Barat. Namun secara parsial pendapatan asli daerah tidak berpengaruh signifikan terhadap perekonomian daerah. Hal ini disebabkan karena pendapatan asli darah yang diterima oleh
Kabupaten/Kota di Provinsi Sumatera Barat habis dipergunakan untuk menutupi biaya-biaya rutin untuk menyelenggarakan pemerintahan daerah sehingga menyebabkan pendapatan asli daerah tersebut belum memberikan pengaruh yang berarti terhadap kondisi perekonomian daerah

2. Investasi swasta, belanja pembangunan, tenaga kerja dan perekonomian daerah secara simultan maupun secara parsial berpengaruh signifikan terhadap pendapatan asli daerah Kabupaten/Kota di Provinsi Sumatera Barat. Semakin banyak pihak swasta yang menginvestasikan modalnya pada daerah, semakin besarnya alokasi dana untuk pembangunan berbagai fasilitas sektor publik, semakin banyak tenaga kerja yang diserap oleh sektor perekonomian akan memberikan kontribusi positif terhadap peningkatan pendapatan asli daerah Kabupaten/Kota di Provinsi Sumatera Barat

\section{Implikasi Kebijakan}

Adapun kebijakan-kebijakan yang dapat disarankan dari hasil penelitian ini adalah sebagai berikut :

1. Dalam upaya meningkatkan perekonomian daerah Kabupaten/Kota di Provinsi Sumatera Barat menjadi lebih baik maka kebijakan yang perlu diambil oleh pemerintah adalah melakukan eksplorasi terhadap sumbersumber pendapatan asli daerah khususnya objek-objek yang dapat meningkatkan penerimaan retribusi daerah dan pendapatan lainnya yang sah.

2. Upaya selanjutnya yang harus dilakukan pemerintah daerah dalam meningkatkan pendapatan asli daerah adalah :

a. Melakukan promosi tentang semua potensi yang dimiliki daerah kepada pihak investor agar pihak dapat meningkatkan jumlah investasi swasta di daerah dan menciptakan iklim investasi yang kondusif pada daerah dengan cara memberikan 
kemudahan bagi investor dalam mengurus birokrasi izin untuk menanamkan investasi di daerah agar sehingga investasi dan akses pasar akan meningkat dan dapat mendorong pertumbuhan sektor riil dalam rangka memperluas kesempatan kerja

b. Meningkatkan alokasi belanja pembangunan yang lebih tinggi agar dapat membangun infrastruktur untuk menunjang aktivitas perekonomian serta meningkatkan penyediaan sarana dan prasarana transportasi melalui pembangunan jalan dan jembatan, pemeliharaan kondisi jalan dan jembatan untuk meningkatkan aksessibilitas wilayah

c. Berupaya semaksimal mungkin untuk peningkatan dari potensi sumber daya manusia agar dapat memberi kontribusi terhadap penerimaan daerah melalui kebijakan yang mampu meningkatkan motivasi tanaga kerja untuk bekerja pada sektor perekonomian yang ada pada masing-masing Kabupaten/Kota serta mau berpindah dari sektor informal ke sektor formal

\section{DAFTAR PUSTAKA}

10.22202/economica.2012.v1.i1.103

Abimanyu, Anggito. 2005. Format Anggaran Terpadu Menghilangkan Tumpang Tindih. Bapekki Depkeu

Adi, Priyo Hari. 2005. Dampak Desentralisasi Fiskal terhadap Pertumbuhan Ekonomi (Studi pada Kabupaten dan Kota Se Jawa Bali). Jurnal Studi Pembangunan KRITIS. Universitas Kristen Satya Wacana. Salatiga.

Arsyad, Lincoln. 1999. Ekonomi Pembangunan. Edisi Keempat. STIE YKPN Yogyakarta

Dornbusch, Rudiger. 2008. Makroekonomi. MGE, Washington.

2004.

Macroeconomics. International Edition. Ninth Edition: Mc Graw Hill.

Gujarati, Damodar. 2003. Ekonometrika Dasar. Alih Bahasa Sumarno Zain, Erlangga., Jakarta.
Guritno Mangkuaubroto, 1993. Ekonomi Publik, PBFE UOM, Yogyakarta

Halim, Abdul. 2001. Analisis Deskriptif Pengaruh Fiscal Stress pada APBD Pemerintah Kabupaten dan Kota di Jawa Tengah. KOMPAK. STIE YO. Yogyakarta. Hal:127-146

Halim, Abdul dan Abdullah, Syukriy 2003. Pengaruh Dana Alokasi Umum (DAU) dan Pendapatan Asli Daerah (PAD) Terhadap Belanja Pemerintah Daerah: Studi Kasus Kabupaten/Kota di Jawa dan Bali. Simposium Nasional Akuntansi VI, 1140-1159

Idris, 2008. Model Analisis Data Kuantitatif Dengan Program SPSS, MM UNP : Padang.

Ismerdekaningsih, Herlina Endah Sri Rahayu.. 2002. Analisis Hubungan Penerimaan Pajak Terhadap Product Domestic Bruto Di Indonesia ( Studi Tahun 1985-2000). ITB Central Library

Kuncoro, Mudrajat. 2004. Otonomi dan Pembangunan Daerah : Reformasi, Perekonomian, Strategi dan Peluang. Penerbit Erlangga

Lin, Justin Yifu dan Zhiqiang Liu. 2000. Fiscal Decentralization and Economic Growth in China, Economic Development and Cultural Change Chicago. Vol 49. Hal : 1-21.

Mankiw, Gregory, N. 2000. Teori Makro Ekonomi. Ed.4, Jakarta: Penerbit Erlangga.

Mankiw, Gregory, N. 2003. Teori Makro Ekonomi, Erlangga: Jakarta.

Mardiasmo. 2002. Otonomi dan Manajemen keuangan Daerah. Penerbit ANDI, Yogyakarta

Meyer, H Laurence. 1980. Macroeconomic ,A Model Building Approach. SouthWestern Publishing Co: Chicago.

Mubyarto. 2003. Teori Investasi dan Pertumbuhan Ekonomi dalam Ekonomi Pancasila, Jurnal Ekonomi Rakyat, Tahun II - No. 4.

Nachrowi, D dan Usman. 2006. Pendekatan Populer dan Praktis Ekonometrika Untuk Analisis Ekonomi dan Keuangan. FE UI: Jakarta.

Pratiwi, Fajar. 2005. Faktor-faktor yang Mempengaruhi Investasi Swasta 
Domestik di Provinsi Jawa Barat 19752003. Tesis S2. Program Pascasarjana UGM.Yogyakarta. (tidak dipublikasikan)

Pancawati, Neni, 2000, Pengaruh Rasio Kapital Tenaga Kerja, Tingkat Pendidikan, Stok Kapital dan Pertumbuhan Penduduk Terhadap Pertumbuhan GDP di Indonesia, Jurnal Ekonomi dan Bisnis Indonesia, Vol 15, No. 2

Ratnawati, Nirdukita dan Rulli Rizki. 2007. Analisis pengaruh variabel indikator ekonomi makro terhadap perekonomian Indonesia: pendekatan pasar barang dan pasar uang (jurnal) periode 1990.1-2005.4. Jurnal Ekonomi Indonesia No. 2 Desember 2007.

Saragih, Juli Panglima. 2003. Desentralisasi Fiskal dan Keuangan Daerah dalam Otonomi. Penerbit Ghalia Indonesia.

Sidik, Machfud. 2002. Perimbangan Keuangan Pusat Dan Daerah Sebagai Pelaksanaan Desentralisasi Fiskal (Antara Teori dan Aplikasinya di Indonesia). Jogyakarta.

Sumodiningrat, Gunawan. 2007. Ekonometrika Pengantar. BPFE: Yokyakarta.

Supriady, Dedy. 2003. Otonomi Penyelenggaraan Pemerintah Daerah. Jakarta : PT. Gramedia Pustaka Utama.

Todaro, Michael. 2004. Pembangunan Ekonomi di Dunia Ketiga. Penerbit Erlangga Edisi Kedelapan

Ulum, Ihyaul. 2010. Analisis Hubungan Peringkat Daya Tarik Investasi dengan Pendapatan Asli Daerah (PAD) Kabupaten/Kota di Indonesia. (Jurnal Akuntansi dan Keuangan Sektor Publik (JAKSP), Volume 7 No. 1, Pebruari 2006. ISSN: $1411-5921)$

Wong, John D. 2004. The Fiscal Impact of Economic Growth and Development on Local Government Capacity. Journal of Public Budgeting., Accounting and Financial Management. Fall. 16.3. Hal : $413-423$

Zaris, Roeslan. 1987. Prespektif Daerah dalam Pembangunan Nasional. Jakarta LPFE UI. 